OPEN ACCESS

Edited by:

Rossano Bolpagni,

Istituto per il Rilevamento

Elettromagnetico dell'Ambiente

(IREA), Italy

Reviewed by:

Khawar Jabran,

Düzce University, Turkey

Rudra Deo Tripathi,

National Botanical Research Institute

(CSIR), India

${ }^{*}$ Correspondence:

Michelle D. Marko

marko@cord.edu

Specialty section:

This article was submitted to

Functional Plant Ecology,

a section of the journal

Frontiers in Plant Science

Received: 01 September 2017 Accepted: 22 November 2018 Published: 10 December 2018

Citation:

Marko MD and White JC (2018) Direct Comparison of Herbicidal or Biological Treatment on Myriophyllum spicatum Control and Biochemistry. Front. Plant Sci. 9:1814. doi: 10.3389/fpls.2018.01814

\section{Direct Comparison of Herbicidal or Biological Treatment on Myriophyllum spicatum Control and Biochemistry}

\author{
Michelle D. Marko ${ }^{*}$ and Jason C. White ${ }^{2}$ \\ ' Department of Biology, Concordia College, Moorhead, MN, United States, ' 2 Department of Analytical Chemistry, \\ The Connecticut Agricultural Experiment Station, New Haven, CT, United States
}

Myriophyllum spicatum or Eurasian watermilfoil (hereafter, milfoil) is among the most problematic invasive aquatic plant species throughout much of North America. M. spicatum infestations can result in reduced diversity and abundance of native plant populations. Control of the invader is essential to promoting healthy ecosystems. Several treatment alternatives are available for milfoil control, although cost and efficacy vary significantly, with some treatments resulting in more harm to the native population than no treatment at all. A series of field-based microcosms containing actively growing milfoil were constructed in order to directly compare the impact of two herbicides (2,4dichlorophenoxyacetic acid and fluridone) and the milfoil weevil (Euhrychiopsis lecontei) on weed control and plant biochemistry. Herbicide concentrations in water, plants, and sediments were monitored, as were weevil population dynamics and resulting invertebrate damage to milfoil stems. The impact of the different treatments on levels of polyphenols, carbohydrates, ash, and overall carbon and nitrogen levels in the milfoil were determined. Total biomass of the untreated milfoil increased by more than 2.7fold during the 53-day experimental period. Conversely, the biomass of milfoil subjected to chemical or biological treatment either remained constant or decreased significantly during the experiment. The herbicide 2,4-D resulted in nearly $100 \%$ milfoil mortality by day 20 , whereas fluridone toxicity was significantly slower but reached $75 \%$ by the end of the trial. Similarly, milfoil growth in the weevil-amended tanks was somewhat erratic but by the end of the trial, the total plant biomass was $71 \%$ less than that of un-amended controls. Although the total biomass remaining at the end of the fluridone and weevil treatments was similar, the carbohydrate and starch content of the shoots in the insect treatment were nearly 4.6- and 4.8-fold greater, respectively, than that of the herbicide treated plants. The higher starch content in insect-treated plants could lead to increased autofragmentation and spread of $M$. spicatum. However, herbicide treatments are frequently required for several years. Therefore, integrated pest management, which combines the long-term benefits of biological controls with the short-term benefits of herbicides may provide the best solution to the control of $M$. spicatum and the conservation of native plants. 


\section{INTRODUCTION}

Eurasian watermilfoil [Myriophyllum spicatum L. (Haloragaceae); hereafter, milfoil] is among the most widespread and aggressive invasive aquatic plants in North America (Smith and Barko, 1990). The native range of M. spicatum is throughout Asia, Europe, and parts of Africa; although its current distribution includes 48 states of the United States, as well as large sections of Canada (EDDMapS, 2015). This broad range is actually quite remarkable; the plant seems to grow just as well after over-wintering under the ice in New England as it does in the year long-growing season of the south. Milfoil is a submersed, rooted perennial dicotyledon that is typically found at average water depths of $0.5-3.5 \mathrm{~m}$. Once introduced to a water body, M. spicatum often grows to form dense stands that outcompete native plants (Smith and Barko, 1990; Madsen et al., 1991). M. spicatum beds can also impede navigation of waterways, and makes boating and swimming dangerous. Direct negative impacts on bird and fish populations have also been documented (Aiken, 1979; Madsen et al., 1995; Schultz and Dibble, 2012; Simbanegavi et al., 2018). M. spicatum reproduction is primarily vegetative, largely explaining its potential for explosive population growth. Spread among lakes can occur by a number of means, including loose vegetation attached to boats/trailers and fragments carried by avian species further threatening native plant populations (Madsen et al., 1988).

A variety of treatment options are available to manage M. spicatum, although the methods can vary significantly in terms of both efficacy and cost. Identifying cost-effective and ecologically sensitive methods of control can reduce impacts on native plant populations. Herbicides are perhaps the most widely employed and effective technique in controlling unwanted aquatic vegetation in the United States (Gettys et al., 2014). There are several contact herbicides listed for aquatic use and although these products cause rapid plant die back, re-growth from unharmed root tissues can be significant. As such, systemic herbicides that impact all plant tissues often provide better longterm control. Two common systemic aquatic herbicides used in the United States are 2,4-dichlorophenoxyacetic acid (2,4-D) and fluridone (Bugbee et al., 2003; Bugbee and White, 2005; Madsen et al., 2014). Whole lake treatments are frequently recommended due to concerns over the chemical dissipation prior to control and as a result, costs can be significant for larger water-bodies. Under some conditions, carefully executed spot treatments can be effective, thereby minimizing impacts to native communities, but permitting and public acceptance can still be issues of concern with herbicides. Herbicides are generally considered to be the most efficient and effective means of M. spicatum control in the United States (Madsen et al., 2014). However, use of herbicides to control submersed aquatic plants is illegal in Europe and herbicide resistance is present in some hybrid milfoils (Poovey and Getsinger, 2007). Herbicides can also result in an abundance of decaying plant biomass in a lake. Therefore understanding the direct impacts of herbicides vs. potential biological control organisms is important to determining the best control options for each unique situation.
There is also much interest in biological control options for invasive aquatic plants such as M. spicatum (Reeves et al., 2008; Havel et al., 2017). Three insects have been associated with declines in M. spicatum populations (see review by Newman, 2004). Cricotopus myriophylli Oliver (Diptera: Chironomidae) has been shown to consume M. spicatum meristems and suppress growth. Acentria ephemerella (Denis and Schiffermüller) (Lepidoptera: Pyralidae) has been shown to decrease M. spicatum biomass in mesocosm experiments and is associated with dramatic decreases in M. spicatum biomass in New York lakes (Johnson et al., 2000; Gross et al., 2001). Euhrychiopsis lecontei (Dietz) (Coleoptera: Curculionidae) may control M. spicatum populations and is particularly interesting as recent studies have shown that the weevil actually prefers the invasive M. spicatum to its native host native milfoil (M. sibiricum Komarov) (Haloragaceae) (Solarz and Newman, 1996, 2001; Sheldon and Jones, 2001). However, due to the lag-time for weevil response to increases in the M. spicatum population, native diversity can be harmed and milfoil populations can become problematic.

The goal of this current study was to directly compare the impact of three different treatment options on M. spicatum under controlled conditions. Two frequently applied systemic herbicides listed for M. spicatum control, 2,4dichlorophenoxyacetic acid and fluridone, were compared to an introduced biocontrol agent, E. lecontei. The impact of these treatments on milfoil biomass, as well as tissue-specific content of polyphenols, carbohydrates, starch, ash, and carbon:nitrogen ratios was determined. A direct comparison of the impacts of the milfoil weevil vs. herbicides in a controlled setting has not been previously performed. This comparison is important piece of determining the optimal means of control in order to reduce the use of herbicides, and encourage long-term planning and restoration.

\section{MATERIALS AND METHODS}

\section{Microcosm Design}

Experimental microcosm tanks were established at Lockwood Farm in Hamden, CT, United States. Sixteen 387 L $(132 \mathrm{~cm} \times 69 \mathrm{~cm} \times 71 \mathrm{~cm}, \mathrm{~L} \times \mathrm{W} \times \mathrm{H})$ tanks (Rubbermaid) were arranged in a randomized block design. Each tank was amended with 32 plastic pots $(10.5 \mathrm{~cm} \times 10.5 \mathrm{~cm} \times 11 \mathrm{~cm})$ containing a lake sediment/agricultural loam (50:50) mix. De-chlorinated tap water was slowly added to a depth of $30 \mathrm{~cm}$. M. spicatum, collected from Lake Quonnipaug, Guilford, CT, United States (Lat. $41.388923^{\circ}$, Lon. $-72.698632^{\circ}$ ), was inspected for damage, cleaned of invertebrates, cut to $20 \mathrm{~cm}$ lengths and planted at a density of four stems per pot. The plants were left to root and establish for approximately 3 weeks. Floating or unestablished stems were replaced daily. Algal growth was minimal throughout the course of the experiment, but removed from tanks by hand when necessary. Water levels were maintained in tanks at approximately $60 \mathrm{~cm}$ or approximately $350 \mathrm{~L}$. 


\section{Experimental Design}

The impact of chemical and biological treatments on plant growth was determined using three treatments with an untreated control. The commercially available formulation of 2,4-dichlorophenoxyacetic acid (2,4-D) recommended for M. spicatum control is Navigate ${ }^{\circledast}$ (Applied Biochemists, Milwaukee, WI, United States); the material is a pelletized butoxyethylester formulation with $27.6 \%$ active ingredient. A second herbicide recommended for M. spicatum control is fluridone, which is commercially available in liquid form as Sonar A.S. ${ }^{\text {TM }}$ (SePRO, Carmel, IN, United States). Both herbicides were added to the experimental tanks at the application rates listed on the label for each product. For Navigate ${ }^{\circledR}$, an application rate of five pounds per $2000 \mathrm{ft}^{2}$ or $1.8 \mathrm{~g}$ per tank is listed to control M. spicatum within 2-3 weeks. With $350 \mathrm{~L}$ of water; this was equivalent to an initial 2,4-D concentration of $1.45 \mathrm{mg} / \mathrm{L}$. For fluridone, a concentration of $40 \mu \mathrm{g} / \mathrm{L}$ in water for 1-2 months is required for control; as such, $36 \mu \mathrm{L}$ was added to each tank. Twenty eight days after this initial application, the fluridone concentration had declined to $12 \mu \mathrm{g} / \mathrm{L}$. At this time, an additional $18 \mu \mathrm{L}$ of fluridone was added to each tank to "bump up" the concentration; this technique is recommended by the manufacturer to sustain effective herbicide levels for the required control period. Aqueous herbicide concentrations were monitored over the duration of the experiment (see below). Each treatment had four replicate tanks.

Cultures of the milfoil weevil E. lecontei, collected from Dooley Pond, Middletown, CT, United States (Lat. 41.5116712 ${ }^{\circ}$, Lon. $-72.6679638^{\circ}$ ), were established in our laboratory approximately 1 month prior to treatment. In order to achieve the desired density of 1-2 weevils per stem known to control M. spicatum (Newman, 2004), ten adult weevils (at least five females) were added to each tank and allowed to oviposit for 10-14 days. M. spicatum meristems were inspected daily to achieve the final density of 1-2 eggs per stem. Weevils typically emerge from pupation after about 25 days (Mazzei et al., 1999); populations were monitored over the subsequent 40 days.

Despite careful inspection and removal of invertebrates at the start of the experiment, some invertebrates remained on the plants or in the collected sediment. Therefore, the damage from weevils along with characteristic damage from other invertebrates, such as snails, caddisflies, A. ephemerella, and Paraponyx sp. was noted. Invertebrate presence and damage was determined through individual inspections of all stems collected from all treatments biweekly. Weevil presence was enumerated by life stage (egg, larva, pupa, adult). Total weevil impact was assessed by presence of any life stage or characteristic larval damage.

\section{Plant Growth}

On a monthly basis, at least two pots of four stems were randomly selected from each replicate tank for determination of biological and chemical parameters. Average values per tank were used for analyses. Biological parameters monitored included weevil density, longest stem length $(\mathrm{cm})$, longest root length $(\mathrm{cm})$, wet and dry mass $(\mathrm{mg})$, as well as a determination of the number of meristems per plant. Plants were separated into plant parts: the top $15 \mathrm{~cm}$ ("tips"), the remaining above ground portion ("middle"), and roots. In biomass analyses, the above ground portions (tips and middle) were combined as above ground treatments.

\section{Plant Chemical Analysis}

Plants were separated into parts (tips, middle, and roots), lyophilized, ground to a fine powder with a coffee grinder (Braun) or mortar and pestle, and weighed for chemical analyses. Chemical analyses included determination of the percent composition of carbon, nitrogen and the elemental carbon:nitrogen ratio, carbohydrates, starch, organics, polyphenols, and ash. Milfoil stems were analyzed for carbon and nitrogen content with a PerkinElmer Series II, CHN/O Analyzer 2400 (Norwalk, CT, United States). Molar ratios of C:N were calculated and used in statistical analyses. Total phenolic compounds (TPC) were determined with the Folin-Ciocalteau assay using tannic acid as the standard (Bowyer et al., 1983). Results were expressed as tannic acid equivalents based on dry mass (TAE). Carbohydrate and starch content were determined by tissue digestion followed by HPLC analysis according to the method of Gent (1984); however, for carbohydrates, the flow rate was modified to $0.6 \mathrm{ml} / \mathrm{min}$. Glucose, fructose, and sucrose concentrations were measured separately and summed for carbohydrate concentrations. Ash content was determined by determining the mass of a dry plant sample before and after heating at $350^{\circ} \mathrm{C}$ for $24 \mathrm{~h}$.

\section{Herbicide Analysis}

The concentrations of 2,4-D and fluridone in the water, sediments, and plant tissues were monitored over the 53 days of the trial. For water, $250 \mathrm{ml}$ samples were taken from the 2,4-D treated tanks on $1,2,6,8,14,21,35$, and 53 days after initial herbicide application. To cleave the ester group from the molecule, $\mathrm{NaOH}(6 \mathrm{M})$ was added to the sample in order to raise the $\mathrm{pH}$ of the water to 12 . After $1 \mathrm{~h}$, the $\mathrm{pH}$ was lowered to 2 by the addition of $6 \mathrm{M} \mathrm{HCl}$. For fluridone, $250 \mathrm{ml}$ water samples were taken $1,2,6,8,14,21,28,35,53,68$, and 84 days after application. Two hundred milliliters aliquots of water containing either 2,4D (acid) or fluridone were subjected to solid phase extraction (SPE) using Bakerbond 6-ml cartridges packed with $500 \mathrm{mg}$ octadecylsilane $\left(\mathrm{C}_{18}\right)$ on vacuum manifold. After sample elution, air was drawn over the cartridges for $5 \mathrm{~min}$. The cartridges were then centrifuged at $500 \mathrm{rpm}$ for $10 \mathrm{~min}$ to remove any remaining water. Each cartridge was eluted with $2.0 \mathrm{ml}$ of methanol that was collected in a chromatography vial. To determine herbicide levels in the sediment, approximately $3.0 \mathrm{~g}$ of air dried sediment was weighed in $20 \mathrm{ml}$ amber vials with Teflon-lined caps. The vials were amended with $15 \mathrm{ml}$ of hexanes and were heated at $65^{\circ} \mathrm{C}$ for $4 \mathrm{~h}$. A 1-ml aliquot of the supernatant was passed through a glass microfiber filter $(0.2 \mu \mathrm{m}$, Laboratory Science Inc., Sparks, NV, United States) and collected in a chromatography vial. To determine the herbicide content of sampled M. spicatum, $1-5 \mathrm{~g}$ of vegetation (root or shoot) was added to a $40 \mathrm{ml}$ amber vial with a Teflon-lined cap. The vials were amended with $20 \mathrm{ml}$ of hexanes and were heated at $50^{\circ} \mathrm{C}$ for $2 \mathrm{~h}$. One-ml aliquots were filtered 
and collected as described above. All hexanes extracts of water, sediment, and vegetation were stored at $-4^{\circ} \mathrm{C}$ prior to analysis.

\section{Herbicide Quantitation}

In water, 2,4-D was quantified by high pressure liquid chromatography (HPLC) (Hewlett-Packard 1100 series) using a Supelco Discovery column $\left(5 \mu \mathrm{m} \mathrm{C}_{18}, 4.6 \mathrm{~mm} \times 250 \mathrm{~mm}\right)$ with a mobile phase of $3: 2$ methanol/1\% glacial acetic acid. The mobile phase flow rate was $1 \mathrm{ml} / \mathrm{min}$ and detection was by ultraviolet diode array at $280 \mathrm{~nm}$. In sediments and plants, the quantitation of 2,4-D was determined on an Agilent (Avondale, PA, United States) 6890 gas chromatograph (GC) with a ${ }^{63} \mathrm{Ni}$ micro-electron capture detector (ECD). An SPB1 film (Supelco, Bellefonte, PA, United States) GC column $(30 \mathrm{~m} \times 0.53 \mathrm{~mm} \times 0.5 \mu \mathrm{m})$ was used and the oven program was as follows: $75^{\circ} \mathrm{C}$ initial temperature ramped at $5^{\circ} \mathrm{C} / \mathrm{min}$ to $206^{\circ} \mathrm{C}$, then ramped at $20^{\circ} \mathrm{C} / \mathrm{min}$ to $280^{\circ} \mathrm{C}$. The injection port was maintained at $250^{\circ} \mathrm{C}$ and a $2-\mu l$ splitless injection was used. The carrier gas over the column was He. The ECD was maintained at $325^{\circ} \mathrm{C}$ and the make-up gas to the detector was $5 \% \mathrm{CH}_{4}$ in $\mathrm{Ar}$ at $60 \mathrm{ml} / \mathrm{min}$. Fluridone was quantified using an Agilent (Avondale, PA, United States) 6890 gas chromatograph (GC) with an Agilent 5973 mass selective detector (MSD) in selective ion monitoring (SIM) mode; the target ion was 328 . The column $(30 \mathrm{~m} \times 250 \mu \mathrm{m} \times 0.25 \mu \mathrm{m})$ contained a MDN-12 film (Supelco, Bellefonte, PA, United States) and the GC program was $180^{\circ} \mathrm{C}$ initial temperature, held for $1 \mathrm{~min}$, then ramped at $10^{\circ} \mathrm{C} / \mathrm{min}$ to $280^{\circ} \mathrm{C}$ and held for $14 \mathrm{~min}$. A $2-\mu 1$ splitless injection was used, the injection port was maintained at $300^{\circ} \mathrm{C}$ and the MS detector was maintained at $280^{\circ} \mathrm{C}$.

\section{Statistical Analysis}

Data were analyzed with SAS 9.1 (SAS Institute Inc., Cary, NC, United States). Milfoil biomass data were tested for normal distribution (K-S test or Shapiro-Wilk test) and variance homogeneity (Levene's test). Extreme outliers were removed. A $\log$ transformation was performed with biomass data that did not meet the tests for normality and homogeneity. Response variables were analyzed separately by plant part. Statistical differences were determined by two-way ANOVA (GLM procedure) using treatment, collection date (DAT, days after treatment) and treatment by DAT interaction. When date was significantly different, response variables were analyzed separately by treatment for each DAT. The 2,4-D treated plants were dead by the last collection of plants and were excluded from analyses of samples on the final collection. The presence of snails, and caddisflies was assessed using a log-linear model (GENMOD procedure, Poison distribution) with treatment and collection date as explanatory variables.

\section{RESULTS}

\section{Treatment Efficacy}

The recoveries of spiked 2,4-D and fluridone from water via SPE were $103 \pm 5.16 \%$ and $135 \pm 13.6 \%$, respectively. Both un-spiked control water samples and pre-treatment tank water samples had
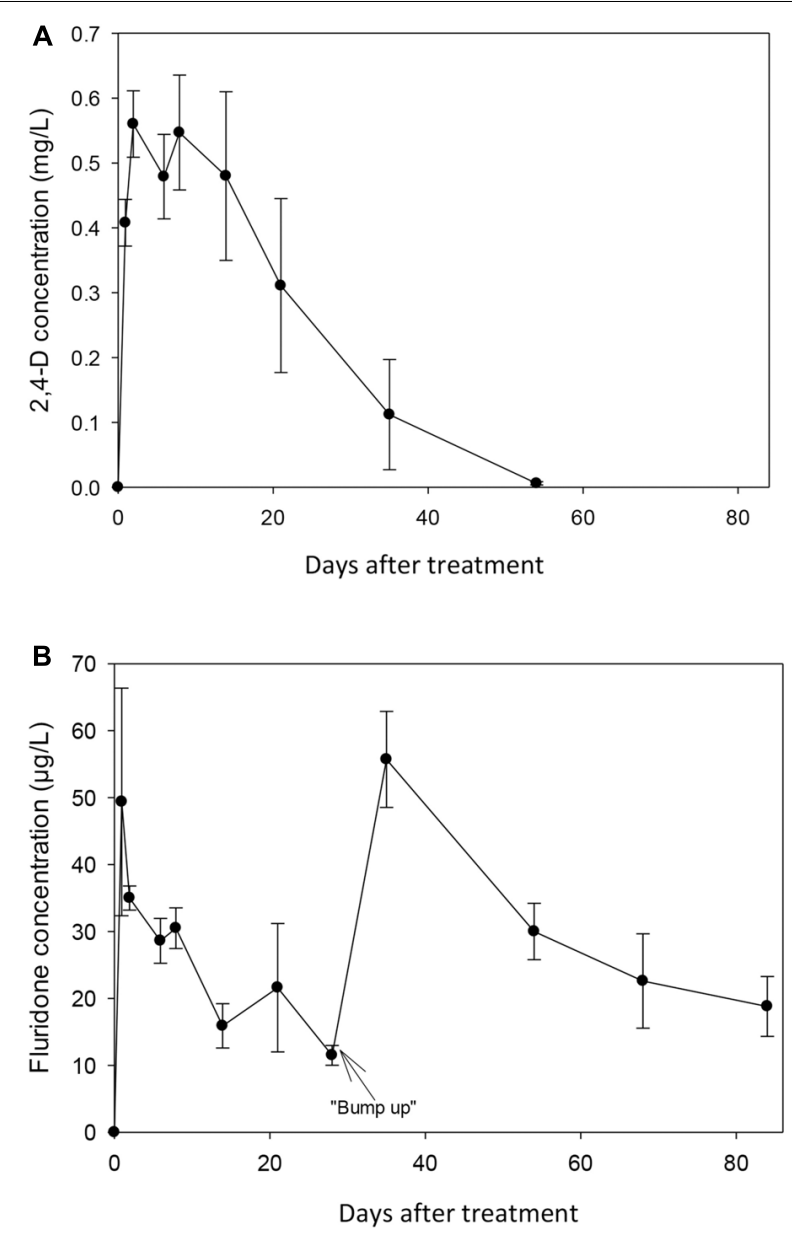

FIGURE 1 | (A) Concentration of 2,4-D (Navigate ${ }^{\circledR}$ ) in the water from tanks treated with the herbicide on $7 / 24 / 2007$. (B) Concentration of fluridone $\left(\right.$ Sonar $^{\mathrm{TM}}$ ) in the water from tanks treated with the herbicide on $7 / 24 / 2007$. Fluridone residuals were measured past the regular experiment to ensure that the dose was maintained for at least $60 \mathrm{~d}$.

non-detectable levels of the herbicides. One day after application, the 2,4-D levels were $0.41 \mathrm{mg} / \mathrm{L}$; at day eight, the concentration was $0.55 \mathrm{mg} / \mathrm{L}$ and subsequently began to decline (Figure 1A). By day 53, the levels were only slightly above the detection limits. One day after application, the fluridone concentration reached $49 \mu \mathrm{g} / \mathrm{L}$ but steadily declined to $12 \mu \mathrm{g} / \mathrm{L}$ on day 28 at which point additional fluridone was added (Figure 1B). By day 38, the concentration had risen to $56 \mu \mathrm{g} / \mathrm{L}$ and steadily decreased to $19 \mu \mathrm{g} / \mathrm{L}$ by day 84 . There were non-detectable levels of both herbicides in the water from control and weevil tanks.

Neither herbicide was detected in sediment samples taken during the exposure period. In addition, 2,4-D was not detected in any of the harvested vegetation. Fluridone was detected in vegetation samples harvested 14 and 48 days after treatment. The average fluridone concentration (dry weight) in harvested milfoil shoots and roots was $31.8( \pm 20.3, \pm 1$ standard deviation) ng/g (dry weight) and 14.3 ( $\pm 20.3, \pm$ SD) ng/g (dry weight), 
TABLE 1 | F-values of two-way ANOVAs with treatment (trt), (trt), date of sample collection (DAT), treatment by DAT interaction (trt $\times$ DAT).

\begin{tabular}{|c|c|c|c|c|c|c|}
\hline & \multicolumn{3}{|c|}{ Shoot } & \multicolumn{3}{|c|}{ Roots } \\
\hline & trt & DAT & trt by DAT & trt & DAT & trt by DAT \\
\hline & df $=3$ & df $=3$ & $\mathrm{df}=6$ & $\mathrm{df}=3$ & $d f=3$ & $\mathrm{df}=6$ \\
\hline Log (wet mass) & $5.67^{*}$ & 2.83 & $17.26^{* * *}$ & $5.68^{*}$ & 1.91 & $11.93^{* * *}$ \\
\hline Log (dry mass) & $4.40^{*}$ & $10.47^{* * *}$ & $15.79^{* * *}$ & 2.91 & $5.18^{* *}$ & $12.13^{* * *}$ \\
\hline Apical meristems & $20.73^{* * *}$ & $18.15^{* * *}$ & $12.81^{* * *}$ & & & \\
\hline Maximum length & $5.34 *$ & 2.59 & $8.50^{* * *}$ & 2.18 & 2.42 & 1.44 \\
\hline
\end{tabular}

Degrees of freedom are: treatment $(d f=3)$, date $(d f=3)$, trt $\times$ date $(d f=6)$, dferror $=24-27$, depending on various missing samples. Significance at $* P<0.05, * * P<0.01$, $* * * P<0.001$. $d f_{\text {error }}=27$, except for dry mass and apical meristems, where $d f_{\text {error }}=26$.

respectively. There were no significant differences in the root or shoot fluridone content between the two sampling periods.

Stable populations of E. lecontei formed in all inoculated tanks reaching the target density of 2 weevils/stem $(2.08 \pm 0.376$, mean $\pm 1 \mathrm{SE})$. Snails were found in all tanks in low numbers throughout the experiment $(0.49 \pm 0.12)$ and were not significantly different by treatment or date after treatment $\left(\chi^{2}=121.5\right.$, df $\left.=131, P>0.1\right)$. Caddisflies were found in many tanks and removed during daily inspections $(0.12 \pm 0.012)$ and were not significantly different by treatment or date after treatment $\left(\chi^{2}=56.4, \mathrm{df}=131, P>0.1\right)$.

\section{Plant Growth}

The log-transformed plant biomass (wet weight) were significantly higher for control treatments than for the herbicide or weevil treated tanks (Table 1 and Figure 2). During the course of the 53 day experiment, the above-ground wet biomass of the control plants increased by 2.7 -fold. Conversely, the wet mass of shoots exposed to weevils or fluridone decreased by 5.5 and $37 \%$, respectively. Plants exposed to 2,4-D lost $57 \%$ of their mass within the first 2 weeks and were completely dead by the end of the trial. Similarly, the wet root biomass was highest for

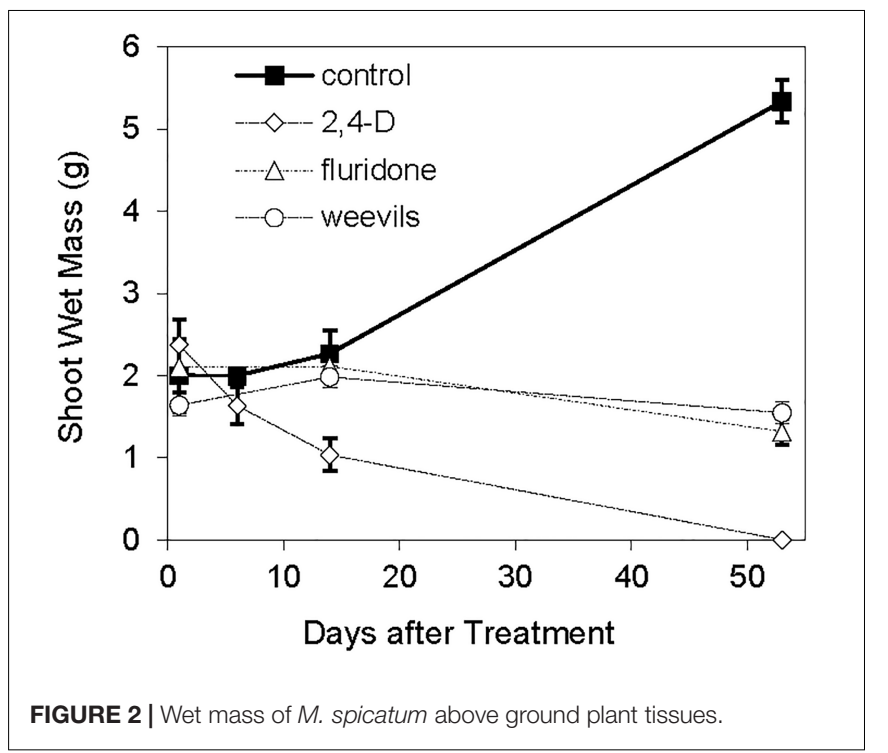

control plants, intermediate for fluridone and weevil-treated plants and lowest for 2,4-D treated plants. Above ground dry biomass was highest for control and weevil-treated plants and lowest for 2,4-D and fluridone-treated plants; the root dry mass of control plants was greater than all treated plants on the final day of the experiment $(P<0.01)$. Lastly, both the number of apical meristems and the average stem length were significantly greater in control plants than the treated plants at the end of the experiment $(P<0.01)$. No significant differences were found in root length between the control and weevil or fluridone treatments; roots were absent in 2,4-D treated plants.

\section{Plant Chemistry}

Percent carbohydrates and starch differed significantly by treatment for all analyzed plant parts (Table 2). The ANOVAs of plant chemistry parameters of milfoil roots and shoots (tips and middle stem) from the control and treatment tanks include polyphenols, ash, and carbon content were statistically equivalent among the different treatments (Table 2). Carbohydrates were greatest in control-treated tips, stems and roots, moderate in weevil-treated tips and stems and least in fluridone-treated tips and stems and fluridone and weevil-treated roots (Figure 3 ). The sugars, fructose, glucose and sucrose followed a similar pattern (Supplementary Figure S1 and Supplementary Table S1). Starch was greatest in weevil-treated tips, control-treated stems and roots, moderate in control-treated tips, and weevil-treated stems and roots and least in fluridone-treated tips, stems and roots (Figure 3). Differences observed in percent carbon reflect the differences observed in carbohydrates and starch. In addition, percent nitrogen increased somewhat for middle stems during the mid-point of the exposure period but then decreased by the end of the trial (data not shown). Percent ash varied little throughout the experiment. Polyphenol content tended to decrease in the stem tips and roots during the experiment but no significant differences existed among the treatments (Figure 3).

\section{DISCUSSION}

The 2,4-D, fluridone, and weevil treatments reduced the growth, carbohydrate and starch content of $M$. spicatum. These findings agree with data from the literature regarding the time course of control achieved with each of the herbicide treatments. The 
TABLE 2 $\mid F$-values of the two-way ANOVAs with treatment, DAT and their interaction as factors for M. spicatum chemical parameters.

\begin{tabular}{|c|c|c|c|c|c|c|c|c|c|}
\hline & \multicolumn{3}{|c|}{ Tips } & \multicolumn{3}{|c|}{ Middle } & \multicolumn{3}{|c|}{ Roots } \\
\hline & trt & DAT & trt $\times$ DAT & trt & DAT & trt $\times$ DAT & trt & DAT & trt $\times$ DAT \\
\hline N & 2.65 & 2.09 & 1.04 & 1.41 & $10.27^{* * *}$ & 0.72 & 1.07 & 2.00 & 2.00 \\
\hline $\mathrm{C}: \mathrm{N}$ & $5.85^{*}$ & $7.34 * *$ & 2.10 & 1.57 & $14.55^{* * *}$ & 1.05 & 0.97 & 0.72 & 1.03 \\
\hline Ash and Organics & 1.07 & $5.47^{*}$ & 0.43 & 1.10 & $8.61^{* *}$ & $3.20^{*}$ & \multicolumn{3}{|c|}{ Sample size too small } \\
\hline Phenols & 1.98 & $8.18^{* * *}$ & $2.88^{*}$ & 1.29 & 2.48 & 0.77 & 2.98 & 2.02 & 0.64 \\
\hline
\end{tabular}

C, percent carbon; N, percent nitrogen; C:N, carbon:nitrogen ratio; Carbs, percent carbohydrates; starch, percent starch; Ash, percent ash; organics, percent organics; phenols, percent polyphenols; trt, treatment; DAT, date of sample collection; treatment by DAT interaction (trt $\times$ DAT). Degrees of freedom are: treatment (df $=3$ ), date $(d f=3)$, trt $\times$ date $(d f=6), d f_{\text {error }}=22-27$, depending on various missing samples, except for Ash, where sample size was very low and df error $=10$ (tips) and 16 (middle). Significance at $* P<0.05,{ }^{* *} P<0.01,{ }^{* * *} P<0.001$.
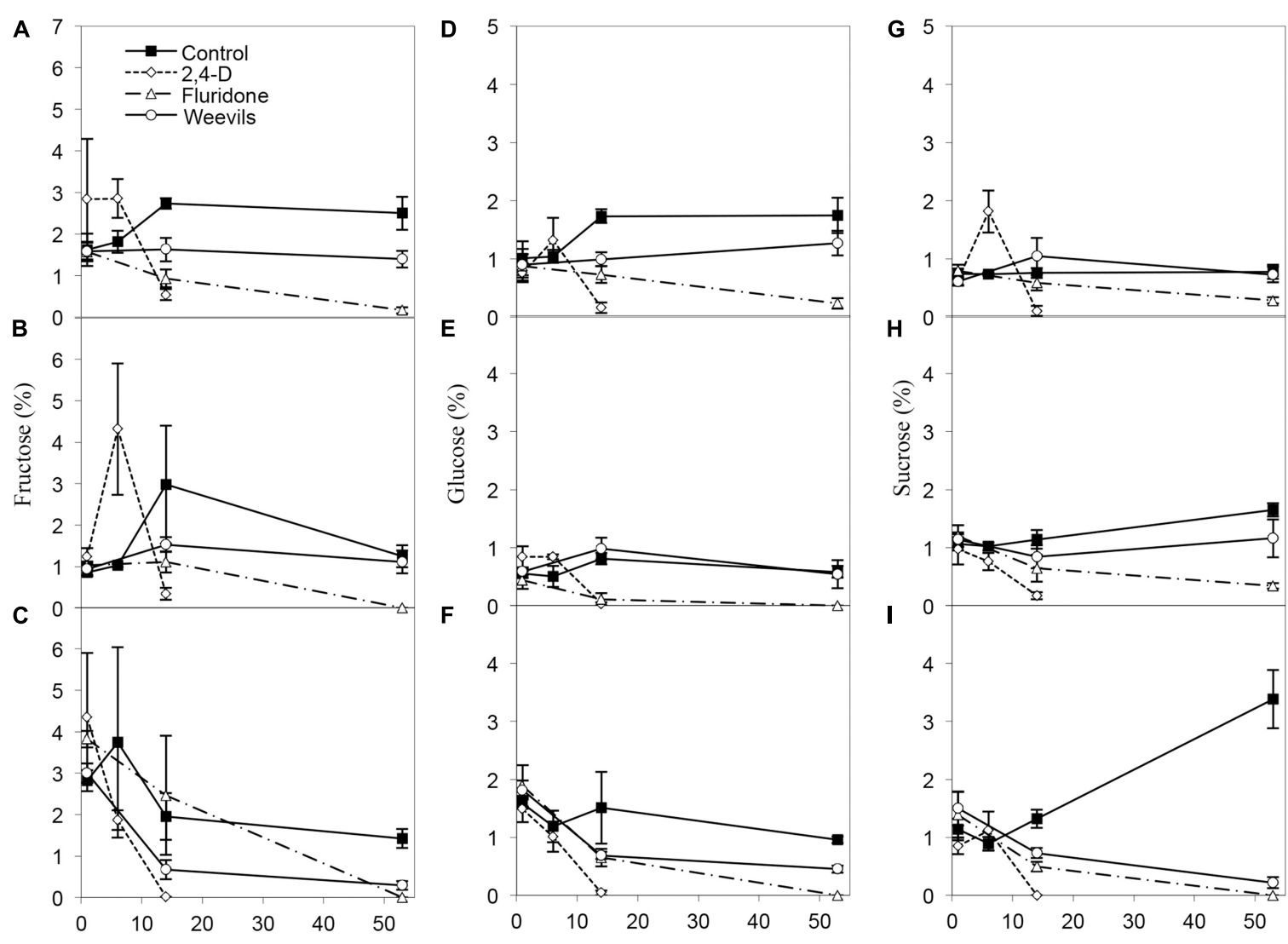

Days after Treatment

FIGURE 3 | Carbohydrate content of (A) tips (34.60 $\pm 3.72 \mathrm{mg} / \mathrm{g}$ dry wt.; mean \pm 1 SE), (B) middle stems (41.30 $\pm 4.03 \mathrm{mg} / \mathrm{g})$, and (C) roots (38.93 $\pm 8.71 \mathrm{mg} / \mathrm{g})$ of M. spicatum in control and treated plants. Starch content of (D) tips (109.59 $\pm 14.02 \mathrm{mg} / \mathrm{g})$, (E) middle stems (117.17 $\pm 14.12 \mathrm{mg} / \mathrm{g})$, and (F) roots $(48.11 \pm 5.9 \mathrm{mg} / \mathrm{g})$ of $\mathrm{M}$. spicatum in control and treated plants. Polyphenol content of (G) tips $(25.68 \pm 4.60 \mathrm{mg} / \mathrm{g})$, (H) middle stems (23.36 $\pm 3.40 \mathrm{mg} / \mathrm{g})$, and (I) roots $(11.86 \pm 1.43 \mathrm{mg} / \mathrm{g})$ of $M$. spicatum in control and treated plants.

systemic herbicide 2,4-D is listed for control on broadleaf or eudicot plants in both terrestrial and aquatic systems. It acts as a plant growth regulator; by mimicking the activity of normal auxin, 2,4-D causes excessive respiration and cell growth, followed by rapid depletion of carbohydrate reserves and plant death (Green and Westerdahl, 1990; Parsons et al., 2001; Bugbee et al., 2003). This was observed for our experiment, where 2,4-D treatments caused an immediate burst of fructose and sucrose concentrations in plant tips, then a reduction of carbohydrate content in the roots after 5 days and rapid losses of carbohydrates 
in above ground tissue by 14 days. Both above and below ground starch content were reduced in 2,4-D treated plants by 5 days.

Fluridone is also a systemic herbicide, although the mode of toxicity and time course of control is quite different from 2,4-D. Fluridone disrupts the biosynthetic pathway for the chlorophyll protecting carotenoids, effectively shutting down photosynthesis (Böger, 1996). New plant tissue is often pale or bleached; the ultimate cause of plant death is essentially starvation (Sprecher et al., 1998). Although the loss of photosynthetic potential can be detected shortly after fluridone exposure (Sprecher et al., 1998), actual plant death can take as long as 1-2 months. Fluridonetreated M. spicatum experienced a gradual loss of carbohydrate content over the course of the experiment, but plant death did not occur until 50 days after treatment.

Weevils also reduced the growth and carbohydrate composition of M. spicatum. Newman et al. (1996) found that weevil stocking reduced total non-structural carbohydrate and sugar content. By day 55 of this experiment, carbohydrate content of control tips, stems and roots was greater than that of weevil-treated plants. When broken down by sugar type, weeviltreated plants had lower fructose and glucose content in plant tips and roots, but similar content in plant stems. Sucrose, often used to transport carbohydrates, was equivalent in control and weevil-treated plant tips and stems, but much lower in weeviltreated roots. One possible explanation is that sugar allocation was impaired by the weevil's stem mining; sugars were produced, but not translocated to growing tips or roots. Unlike glucose and fructose, the starch content of weevil-treated meristems tips was greater than that of control-tips. This puzzling result could be in preparation of the production autofragments (Madsen, 1997). Because the sugars could not be translocated to roots, plants actively produce autofragments instead, potentially leading to the spread of M. spicatum and the production of new plants. In some meristems, the initiation of roots was observed.

The movement of carbohydrates (sugars and starch) highlighted the similarities and differences in resource allocation between herbicide and stem-mining treatments. The carbohydrate content in roots was equivalent for weeviltreated and fluridone-treated plants, which were both low by late summer. Madsen (1997) suggested herbicides should be applied when carbohydrates are at their minimum concentration, often occurring just before regrowth in the spring. However, he noted that for some populations, a late season minimum might also be found at which point herbicides may also be maximally effective (Madsen, 1997). Late summer minima in carbohydrate content has been observed in some milfoil populations from Minnesota lakes (Newman and Biesboer, 2000) and in other plant species (Madsen and Owens, 1998; Marko et al., 2015). This study showed that weevils and herbicides applied during early summer growth could limit carbohydrate allocation to roots in the fall, which should reduce M. spicatum growth the following Spring.

A notable difference in weevil and herbicide treatments was the higher carbohydrate content in weevil-treated plant tips and stems. This indicated that while fluridone treated plants stopped producing sugars and slowly used up their reserves, weeviltreated plants were left with starch in the plant tips, which could be used to make fragments. Our treatments indicate that weevil biocontrol may increase autofragmentation of M. spicatum, thereby leading to its spread; further impacting native plant communities. While both fluridone and weevils may harm future plant growth, only herbicides prevented autofragmentation.

Controlled laboratory studies suggest that $1-2 \mathrm{mg} / \mathrm{L}$ of $2,4-\mathrm{D}$ for a 24-48 h period will result in complete M. spicatum control (Getsinger and Netherland, 1997). Under field conditions, salt and butoxyethylester formulations of 2,4-D have been used to effectively manage M. spicatum (Bugbee and White, 2005), as well as other problematic plants such as variable milfoil (M. heterophyllum Michx.) (Haloragaceae) (Bugbee et al., 2003) and water chestnut (Trapa natans L.) (Trapaceae) (Poovey and Getsinger, 2007). Although whole-lake treatments are typically recommended, such efforts can be cost-prohibitive. It is noteworthy that several of the field studies listed above involved spot applications in larger lakes. As a result, measured aqueous concentrations of 2,4-D are often well below the laboratory obtained control values of $1-2 \mathrm{mg} / \mathrm{L}$; in fact, concentrations as low as $0.10 \mathrm{mg} / \mathrm{L}$ have still been associated with significant weed death (Bugbee and White, 2005). In our microcosm trials, the highest measured aqueous concentration of 2,4-D was $0.55 \mathrm{mg} / \mathrm{L}$ and by day 20 the concentration had dropped to approximately $0.30 \mathrm{mg} / \mathrm{L}$. Nonetheless, nearly complete control of $M$. spicatum was observed in these microcosms, suggesting that concentrations of less than $1.0 \mathrm{mg} / \mathrm{L}$ are likely to be effective. Use of low herbicide concentrations may suggests that spot treatments and lower whole-lake herbicide concentrations may be effective management tools in promoting a healthy aquatic plant community and help to alleviate concerns regarding herbicide use.

Reductions in photosynthetic potential can be detected within a few days of fluridone exposures as low as 0.002$0.005 \mathrm{mg} / \mathrm{L}$ (Sprecher et al., 1998). However, the product label suggests aqueous concentrations of $0.010-0.070 \mathrm{mg} / \mathrm{L}$ for at least 2 months. Netherland et al. (1997) noted that in a mesocosm study, fluridone at $0.005 \mathrm{mg} / \mathrm{L}$ could exert greater than $90 \%$ control on $M$. spicatum over 90 days without significantly impacting several non-target species but that at concentrations of $0.010-0.020 \mathrm{mg} / \mathrm{L}$, impact on other species became significant. Bugbee and White (2005) noted that in a field experiment with spot applications of fluridone, cabomba (Cabomba caroliniana A. Gray) (Cabombaceae) could be effectively controlled at concentrations as low as $0.006 \mathrm{mg} / \mathrm{L}$, but only if those levels were sustained for 60-70 days by repeated or "bump-up" applications. Interestingly, this level of fluridone exposure had no impact on the low growing robbins pondweed (Potamogeton robbinsii Oakes) (Potamogetonaceae) within the treatment area but did significantly reduce non-target lily pads that were also present. In the current microcosm trials, concentrations peaked within the first 2 days and began to decrease quickly; as in the field study of Bugbee and White (2005), a "bump-up" application was necessary to maintain suitable levels. In agreement with the literature, an average concentration of approximately $0.025 \mathrm{mg} / \mathrm{L}$ resulted in $75 \%$ control over the course of the 60 day trial.

The greater values for biomass, stem length and apical meristem numbers found for control plants clearly indicate 
that the weevil- and herbicide-treated plants were harmed by the treatments. The milfoil treated with 2,4-D were most negatively affected. Weevil- and fluridone-treated plants were very similar in terms of their measured physical responses but statistically significant differences were observed in their morphological and chemical properties. In particular, fluridonetreated plants lost photosynthetic pigments and capability, followed by stunted growth. Conversely, weevil-treated plants maintained photosynthetic potential but affected meristems were consumed and stems were hollowed out. This could result in weevil-treated plants producing autofragments, whereas fluridone-treated plants did not. Depending on the spread of the invasive species within the lake, herbicide treatments may be; more effective at reducing the potential for the spread of M. spicatum. However, herbicide treatments often must be applied annually for several years before the invasive plant is brought to acceptable levels; whereas biological controls may only need to be applied once and are species specific (Hussner et al., 2017).

The use of the milfoil weevil for the biological control of M. spicatum is considered augmentative biocontrol because a native herbivore is being supplemented (Hussner et al., 2017). While the control of emergent and floating-leaf aquatic plants has been successful, the control of submersed aquatic plants has been more difficult (McFadyen, 1998; Newman, 2004; Hussner et al., 2017). As seen in this study, biocontrol organisms can provide localized biomass reduction. Unfortunately, those short-term impacts do not always translate to long-term control (Newman, 2004). Biocontrol populations can fluctuate year to year due to environmental factors such as poor overwintering habitat, fish predation and difficulty with migration to healthy weed patches (Newman, 2004; Hussner et al., 2017). Hussner et al. (2017) suggests that biological control organisms for submersed aquatic plants are best considered as part of an integrated pest management plan.

The differences observed among the treatments in plant carbohydrate and starch content highlight the different impacts that herbicides and weevils have on milfoil plants. While 2,4-D-treated plants simply die off and the concentrations of both starch and carbohydrates decline dramatically, the differences between the fluridone-and weevil-treated plants are more subtle. Carbohydrate content in weevil-treated tip and middle stems remains higher than fluridone-treated plants throughout the experiment, but carbohydrate content in roots in weevil- and fluridone-treated plants is similarly quite low. This demonstrates the different modes of action in fluridone and weevil treatments. Fluridone directly impacts photosynthetic potential, which obviously results in carbohydrate reduction over time. Conversely, weevils do not impact carbohydrate production, but do impact its translocation. Both effects result in lower starch content in the roots, which would subsequently result in lower over-winter survival.

In addition to production and translocation of carbohydrates, the production of defensive chemicals can indicate how welldefended the plant is against herbivores, and therefore how susceptible it is to biological control organisms. Polyphenol production is a common defensive mechanism of plants and these chemicals are known to be abundant in milfoils (Marko et al., 2008; Fornoff and Gross, 2014). Polyphenol concentrations varied only slightly over time in M. spicatum tips and were not different by treatment for any plant part suggesting polyphenol production is constitutive or not induced by herbivory of the specialist weevil. As E. lecontei is a milfoil specialist, it is unlikely to be impacted by polyphenol content (Marko and Newman, 2017). However, polyphenols due play an important role in the defense of $M$. spicatum against algae (Gross et al., 1996) and the generalist A. ephemerella (Fornoff and Gross, 2014).

Based on our results, the milfoil weevil would be a more effective control when used with fluridone than with 2,4D. The herbicide 2,4-D resulted in the rapid die-back of M. spicatum, whereas plants treated with fluridone were healthier longer. Fluridone has been used as an effective control of invasive submersed plants while maintaining healthy native plant communities (Bremigan et al., 2005; Pedlow et al., 2006). However, fluridone treatments have also resulted in the decline of native plant communities (Valley et al., 2006; Parsons et al., 2009) or resulted in increased invasive plant growth several years after treatment (Wagner et al., 2007). The use of E. lecontei with fluridone could result in the biomass reduction of $M$. spicatum. The longer senescence times when using fluridone may provide the milfoil weevil with enough opportunity to find healthy milfoil. Spot-treatments of fluridone leaving nearby healthy $M$. spicatum populations would provide the best chance for successful integration of herbicide and biocontrol organisms as the slow senescence of fluridone and the nearby healthy population of $M$. spicatum would provide E. lecontei with the time to move to a refuge.

\section{CONCLUSION}

In conclusion, $M$. spicatum was effectively controlled by both chemical and biological methods. The herbicide 2,4-D resulted in rapid and complete weed death, whereas the herbicide fluridone and the biological control agent E. lecontei yielded 70-75\% control during the 53 day trial. Although total biomass remaining was similar between fluridone- and E. lecontei-treated plants, clear biochemical differences among the surviving vegetation could be detected and these differences were directly related to differential modes of action. While all treatments did reduce $M$. spicatum biomass, no one treatment stood out as the most effective way to control M. spicatum for the promotion of native species growth. Both herbicides show mixed results against native vegetation in field trials and both often result in longterm regrowth of the invasive species. E. lecontei alone does not seem to adequately control $M$. spicatum on a yearly basis, but it does provide the only possibility of long-term control and has no negative non-target impacts. The most effective long-term control to of $M$. spicatum to promote the growth of native vegetation is likely an integration of management choices. 


\section{AUTHOR CONTRIBUTIONS}

All authors equally participated the all aspects of this project from design, data collection, and analysis to drafting of this manuscript.

\section{FUNDING}

This work was funded partially through the US EPA Pesticide Environmental Stewardship Program (PESP Grant \#97166101-0).

\section{ACKNOWLEDGMENTS}

We thank Terri Arsenault, Alicia Bridgewater, Flynn Boonstra, Kathryn Mann, and Annette Russell for technical assistance. We

\section{REFERENCES}

Aiken, S. G. (1979). North American Species Of Myriophyllum (Haloragaceae). Ph.D. thesis, University of Minnesota, St. Paul. Minnesota, MN.

Böger, P. (1996). Mode of action of herbicides affecting carotenogensis. J. Pestic. Sci. 21, 473-478. doi: 10.1584/jpestics.21.473

Bowyer, J. R., Hallahan, B. J., and Box, J. D. (1983). Investigation of the FolinCiocalteau phenol reagent for the determination of polyphenolic substances in natural waters. Water Res. 17, 511-525. doi: 10.1016/0043-1354(83) 90111-2

Bremigan, M. T., Hanson, S. M., Soranno, P. A., Cheruvelil, K. S., and Valley, R. D. (2005). Aquatic vegetation, largemouth bass and water quality responses to low-dose fluridone two years post treatment. J. Aquat. Plant Manage. 43, 35-75.

Bugbee, G. J., and White, J. C. (2005). Control of Cabomba and Eurasian Milfoil in Lake Quonnipaug with Fluridone and 2,4-D, 2001. New Haven, CT: CAES Bulletin 998.

Bugbee, G. J., White, J. C., and Krol, W. (2003). Control of variable watermilfoil in bashan lake CT with 2,4-D: monitoring of lake and well water. J. Aquat. Plant Manage. 41, 18-25.

EDDMapS. (2015). Early Detection and Distribution Mapping System (EDDMapS). Myriophyllum Spicatum L. https://www.eddmaps.org/Species/subject.cfm?sub= 3055. Site accessed. 23 August (2017)

Fornoff, F., and Gross, E. M. (2014). Induced defense mechanisms in an aquatic angiosperm to insect herbivory. Oecologia $175,173-185$. doi: 10.1007/s00442013-2880-8

Gent, M. P. N. (1984). Carbohydrate level and growth of tomato plants. Plant Physiol. 76, 694-699. doi: 10.1104/pp.76.3.694

Getsinger, K. D., and Netherland, M. D. (1997). "Herbicide Concentration/Exposure Time Requirements for Controlling Submersed Aquatic Plants: Summary of Research Accomplishments. Summary of Research Accomplishments" Miscellaneous Report A-97-2. (Vicksburg, MS: U.S. Army Engineer Waterways Experiment Station).

Gettys, L. A., Haller, W. T., and Petty, D. G. (2014). Biology and Control of Aquatic Plants: A Best Management Practices Handbook, 3rd Edn. Fond du Lac, WI: Aquatic Ecosystem Restoration Foundation.

Green, W. R., and Westerdahl, H. E. (1990). Response of Eurasian watermilfoil to 2,4-D concentrations and exposure time. J. Aquat. Plant Manage. 28, 27-32.

Gross, E. M., Johnson, R. L., and Hairston, N. G. jr., (2001). Experimental evidence for changes in submersed macrophyte species composition caused by the herbivore Acentria ephemerella (Lepidoptera). Oecologia 127, 105-114. doi: 10.1007/s00442 0000568

Gross, E. M., Meyer, H., and Schilling, G. (1996). Release and ecological impact of algicidal hydrolyzable polyphenols in Myriophyllum spicatum. Phytochemistry 41, 133-138. doi: 10.1016/0031-9422(95)00598-6 also thank Dr. Martin Gent for assistance with carbohydrate analyses.

\section{SUPPLEMENTARY MATERIAL}

The Supplementary Material for this article can be found online at: https://www.frontiersin.org/articles/10.3389/fpls.2018.01814/ full\#supplementary-material

FIGURE S1 | Fructose content of (A) tips (1.70 $\pm 0.24 \mathrm{mg} / \mathrm{g}$ dry wt.; mean \pm 1 SE), (B) middle stems (1.36 $\pm 0.31 \mathrm{mg} / \mathrm{g})$, and $\mathbf{( C )}$ roots $(2.03 \pm 0.41 \mathrm{mg} / \mathrm{g})$ of M. spicatum in control and treated plants. Glucose content of (D) tips $(0.98 \pm 0.13 \mathrm{mg} / \mathrm{g})$, (E) middle stems $(0.52 \pm 0.088 \mathrm{mg} / \mathrm{g})$ and $(\mathbf{F})$ roots $(1.02 \pm 0.17 \mathrm{mg} / \mathrm{g})$ of $M$. spicatum in control and treated plants. Sucrose content of $\mathbf{G})$ tips $(0.74 \pm 0.11 \mathrm{mg} / \mathrm{g})$, (H) middle stems $(0.94 \pm 0.11 \mathrm{mg} / \mathrm{g})$ and $\mathbf{( I )}$ roots $(1.00 \pm 0.24 \mathrm{mg} / \mathrm{g})$ of $\mathrm{M}$. spicatum in control and treated plants.

TABLE S1 | $F$-values of the two-way ANOVAs with treatment, DAT and their interaction as factors for $M$. spicatum chemical parameters.

Havel, J. E., Knight, S. E., and Maxson, K. A. (2017). A field test on the effectiveness of milfoil weevil for controlling Eurasian watermilfoil in wisconsin lakes. Hydrobiologia 800, 81-97. doi: 10.1007/s10750-017-3142-2

Hussner, A., Stiers, I., Verhofstad, M. J. J. M., Bakker, E. S., Grutters, B. M. C. Haury, J., et al. (2017). Management and control methods of invasive alien freshwater aquatic plants: a review. Aquat. Bot. 136, 112-137. doi: 10.1016/j. aquabot.2016.08.002

Johnson, R. L., van Duesen, P. J., Toner, J. A., and Hairston, N. G. Jr., (2000). Eurasian watermilfoil biomass associated with insect herbivores in New York. J. Aquat. Plant Manage. 38, 82-88.

Madsen, J. D. (1997). Seasonal biomass and carbohydrate allocation in a southern population of Eurasian watermilfoil. J. Aquat. Plant Manage. 35, 15-21. doi: 10.21236/ADA327968

Madsen, J. D., Eichler, L. W., and Boylen, C. W. (1988). Vegetative spread of Eurasian watermilfoil in Lake George, New York. J. Aquat. Plant Manage. 26, 47-50.

Madsen, J. D., Gettys, L. A., Haller, W. T., and Petty, D. G. (2014). Chapter 15.2. Eurasian watermilfoil. in Biology and Control of Aquatic Plants: A Best Management Practices Handbook, 3rd Edn. Marietta, GA: Aquatic Ecosystem Restoration Foundation, 121-124.

Madsen, J. D., and Owens, C. S. (1998). Seasonal biomass and carbohydrate allocation in dioecious hydrilla. J. Aquat. Plant Manage. 36, 138-145.

Madsen, J. D., Smart, R. M., Dick, G. O., and Honnell, D. R. (1995). “The influence of an exotic submersed aquatic plant, Myriophyllum spicatum, on water quality, vegetation and fish populations of Kirk Pond, Oregon," in Proceedings, 29th Annual Meeting, Aquatic Plant Control Research Program, (Vicksburg, MS: US Army Corps of Engineers Waterways Experiment Station).

Madsen, J. D., Sutherland, J. W., Bloomfield, J. A., Eichler, L. W., and Boylen, C. W. (1991). The decline of native vegetation under dense Eurasian watermilfoil canopies. J. Aquat. Plant Manage. 29, 94-99.

Marko, M. D., Gross, E. M., Newman, R. M., and Gleason, F. K. (2008). Chemical profile of the North American native Myriophyllum sibiricum compared to the invasive M. spicatum. Aquat. Bot. 88, 57-65. doi: 10.1016/j.aquabot.2007.08.007

Marko, M. D., Madsen, J. D., Smith, R. A., Sartain, B., and Olson, C. L. (2015). Ecology and phenology of flowering rush in the detroit lakes chain of lakes, Minnesota. J Aquat. Plant Manage. 53, 54-63.

Marko, M. D., and Newman, R. M. (2017). Fecundity of a native herbivore on its native and exotic host plants and relationship to plant chemistry. Aquat. Invasions 12, 355-369. doi: 10.3391/ai.2017.12.3.09

Mazzei, K. C., Newman, R. M., Loos, A., and Ragsdale, D. W. (1999). Developmental rates of the native milfoil weevil, Euhrychiopsis lecontei, and damage to Eurasian watermilfoil at constant temperatures. Biol. Control 16, 139-143. doi: 10.1006/bcon.1999.0739

McFadyen, R. E. C. (1998). Biological control of weeds. Ann. Rev. Entomol. 43, 369-393. doi: 10.1146/annurev.ento.43.1.369 
Netherland, M. D., Getsinger, K. D., and Skogerboe, J. D. (1997). Mesocosm evaluation of the species-selective potential of fluridone. J. Aquat. Plant Manage. 35, 41-50.

Newman, R. M. (2004). Biological control of Eurasian watermilfoil by aquatic insects: basic insights from an applied problem. Arch. Hydrobiol. 159, 145-184. doi: 10.1127/0003-9136/2004/0159-0145

Newman, R. M., and Biesboer, D. D. (2000). A decline of Eurasian watermilfoil in Minnesota associated with the milfoil weevil, Euhrychiopsis lecontei. J. Aquat. Plant Manage. 28, 105-111.

Newman, R. M., Holmberg, K. L., Biesboer, D. D., and Penner, B. G. (1996). Effects of the potential biological control agent, Euhrychiopsis lecontei, on Eurasian watermilfoil in experimental tanks. Aquat. Bot. 53, 131-150. doi: 10.1016/03043770(95)01005-X

Parsons, J. K., Couto, A., Hamel, K. S., and Marx, G. E. (2009). Effect of fluridone on macrophytes and fish in a coastal Washington lake. J. Aquat. Plant Manag. 47, 31-40.

Parsons, J. K., Hamel, K. S., Madsen, J. D., and Getsinger, K. D. (2001). The use of 2,4-D for selective control of an early infestation of Eurasian watermilfoil in Loon Lake, Washington. J. Aquat. Plant Manage. 39, 117-125.

Pedlow, C. L., Dibble, E. D., and Getsinger, K. D. (2006). Littoral habitat heterogeneity and shifts in plant composition relative to a fall whole-lake fluridone application in Perch Lake, Michigan. J. Aquat. Plant Manage. 44, 26-31.

Poovey, A. G., and Getsinger, K. D. (2007). Subsurface applications of triclopyr and 2,4-D amine for control of water chestnut (Trapa natans L.). J. Aquat. Plant Manage. 45, 63-66.

Reeves, J. L., Lorchi, P. D., Kershner, M. W., and Hilovsky, M. A. (2008). Biological control of Eurasian watermilfoil by Euhrychiopsis lecontei: assessing efficacy and timing of sampling. J. Aquat Plant Manage. 46, 144-149.

Schultz, R., and Dibble, E. (2012). Effects of invasive macrophytes on freshwater fish and macroinvertebrate communities: the role of invasive plant traits. Hydrobiologia 684, 1-14. doi: 10.1007/s10750-011-0978-8

Sheldon, S. P., and Jones, K. N. (2001). Restricted gene flow according to host plant in an herbivore feeding on native and exotic watermilfoils (Myriophyllum: Haloragaceae). Int. J. Plant Sci. 162, 793-799. doi: 10.1086/320785
Simbanegavi, T. T., Ndagurwa, H. G. T., Mundava, J., and Mundy, P. J. (2018). Response of the waterbird community to floating pennywort (Hydrocotyle ranunculoides) cover at Ngamo dam, Antelope Park, Zimbabwe. Afr. J. Ecol. 56, 20-27. doi: 10.1111/aje.12412

Smith, C. S., and Barko, J. W. (1990). Ecology of Eurasian watermilfoil. J. Aquat. Plant Manage. 28, 55-64. doi: 10.1371/journal.pone.0120248

Solarz, S. L., and Newman, R. M. (1996). Oviposition specificity and behavior of the watermilfoil specialist Euhrychiopsis lecontei. Oecologia 106, 337-344. doi: 10.1007/BF00334561

Solarz, S. L., and Newman, R. M. (2001). Variation in hostplant preference and performance by the milfoil weevil, Euhrychiopsis lecontei Dietz, exposed to native and exotic watermilfoils. Oecologia 126, 66-75. doi: 10.1007/ s004420000484

Sprecher, S. L., Netherland, M. D., and Stewart, A. B. (1998). Phytoene and carotene response of aquatic plants to fluridone under laboratory conditions. J. Aquat. Plant Manage. 36, 111-120.

Valley, R. D., Crowell, W., Welling, C. H., and Proulx, N. (2006). Effect of a lowdose Fluridone treatment on submersed aquatic vegetation in a eutrophic Minnesota lake dominated by Eurasian watermilfoil and coontail. J. Aquat. Plant Manage. 44, 19-25.

Wagner, I., Hauxwell, J., Rasmussen, P. W., Koshere, F., Toshner, P., Aron, K., et al. (2007). Whole-lake herbicide treatments for Eurasian watermilfoil in four Wisconsin lakes: effects on vegetation and water clarity. Lake Reserv. Manage. 23, 83-94. doi: 10.1080/07438140709353912

Conflict of Interest Statement: The authors declare that the research was conducted in the absence of any commercial or financial relationships that could be construed as a potential conflict of interest.

Copyright (c) 2018 Marko and White. This is an open-access article distributed under the terms of the Creative Commons Attribution License (CC BY). The use, distribution or reproduction in other forums is permitted, provided the original author(s) and the copyright owner(s) are credited and that the original publication in this journal is cited, in accordance with accepted academic practice. No use, distribution or reproduction is permitted which does not comply with these terms. 